\title{
Relationship of macroinvertebrate species and mangrove species in Xuan Thuy National Park, Vietnam
}

\author{
Mối quan hệ của các loài động vật không xưong sống cõ lớn với các loài cây \\ ngập mặn ở Vườn quốc gia Xuân Thủy, Việt Nam \\ Research article
}

Haneji, Choshin ${ }^{1}$; Do, Van Tu²; Nguyen, The Cuong ${ }^{2}$; Tran, Thi Phuong Anh ${ }^{3}$

${ }^{1}$ Graduate School of Environment and Information Sciences, Yokohama National University, Japan; ${ }^{2}$ Institute of Ecology and Biological Resources, Vietnam Academy of Science and Technology; ${ }^{3}$ Vietnam National Museum of Nature, Vietnam Academy of Science and Technology

\begin{abstract}
Associative relationships among mangrove species and macroinvertebrate species were analysed for ecosystems of Xuan Thuy National Park. Census of mangrove species with allometric measurements was conducted in selected plots, and census of macroinvertebrate species was conducted in quadrats inside of mangrove species census plots. Correlational analysis among allometrically estimated aboveground biomass of mangrove species and population of macroinvertebrate species was examined by clustering method. High level of similarity was resulted for specific macroinvertebrate species with specific mangrove species in annual and seasonal basis. Moreover, indicator macroinvertebrate species is proposed based on indicator value index method.

Các mối quan hệ giữa thực vật ngập mặn và động vật không xưong sống cỡ lớn được phân tích trong các hệ sinh thái của Vườn quốc gia Xuân Thủy. Khảo sát về số luợng của các loài cây ngập mạn cùng với các phép đo tương quan sinh truởng được tiến hành trong các ô tiêu chuẩn, và nghiên cứu về thành phần loài và mật độ động vật không xương sống cỡ lớn được thưc hiện trong các ô tiêu chuẩn này. Phân tích tương quan giữa sinh khối ước tính trên mặt đất của các loài cây ngập mặn và các quần thể động vật không xương sống cõ̃ lớn đã được thực hiện bằng phưong pháp nhóm. Giũa các loài động vật không xưong sống cỡ lớn đặc trung với các loài cây ngập mặn đặc trung đã cho thấy mức độ tương đồng cao theo năm và theo mùa. Hơn thế nũa, các loài động vật không xuơng sống cõ lớn chỉ thị được đề xuất dụa trên phuơng pháp chỉ số giá trị chỉ thị.
\end{abstract}

Keywords: Xuan Thuy National Park, macroinvertebrate species, mangrove ecosystem

\section{Introduction}

Xuan Thuy National Park (XTNP) is distributed in the Ba Lat estuary area of Red river, in Nam Dinh province, around $90 \mathrm{~km}$ at southeast of Hanoi.

Based on the information from Hong et al. (2007), the core zone of XTNP consists of Ngan islet's northeastern area and the whole of $\mathrm{Lu}$ and Xanh islets. The zone distributes 3,100 ha of land and 4,000 ha of wetland at low tide, with a total extension of 7,100 ha. The coastal area of XTNP lies in the tropical monsoon region with two distinct seasons: a hot and rainy season occurring from
April to October and a cold and dry season occurring from November to March.

According to Giesen et al. (2006), XTNP pertains to the Northern Delta Zone of Vietnam's mangrove forests. The area is formed by accretion of sediments from the Red river. Although the mudflats are large and rich in alluvium and freshwater, this zone is subjected to strong winds, storms and waves. Also, as winter temperatures are low, mangrove species stands are not extensive and the trees are relatively small.

Generally, mangrove forests in the XTNP can be classified into natural and planted mangrove forests. The natu- 
ral mangrove forests are mainly distributed in the northern area of the Park, dominated by the species Aegiceras corniculatum and Sonneratia caseolaris (Wösten et al., 2003). The planted mangrove forests are mainly distributed in the southern part, dominated by species of genus Kandelia (Tue et al., 2012). Significant communities of Avicennia spp., Kandelia candel, and Rhizophora stylosa are also present (Wösten et al., 2003).

The present work analyses the interrelationships among the mangrove species and macroinvertebrate species of $\mathrm{XTNP}$, in order to provide basic indicators for the biodiversity therein.

\section{Materials and methods}

\subsection{Mangrove species census}

Taking into account the information collected from the bibliographic survey on the mangrove ecosystem of XTNP, and on the field reconnaissance works at initial stage of survey conducted in December 2012 (Haneji et al., 2014), it was decided to establish three locations for the monitoring of mangrove species.

Census of mangrove species was conducted in three plots (P1, P2, and P5: Figure 1) of $400 \mathrm{~m}^{2}$ (20 m by $\left.20 \mathrm{~m}\right)$ each in July and December 2013. Census was performed, by total counting of identified species, measuring their heights, and stem diameter at breast height and average stem diameter for lower individuals. The aboveground biomass (AGB) of mangrove species was estimated using the allometric equations proposed by Komiyama et al. (1988) based on the measured allometric data.

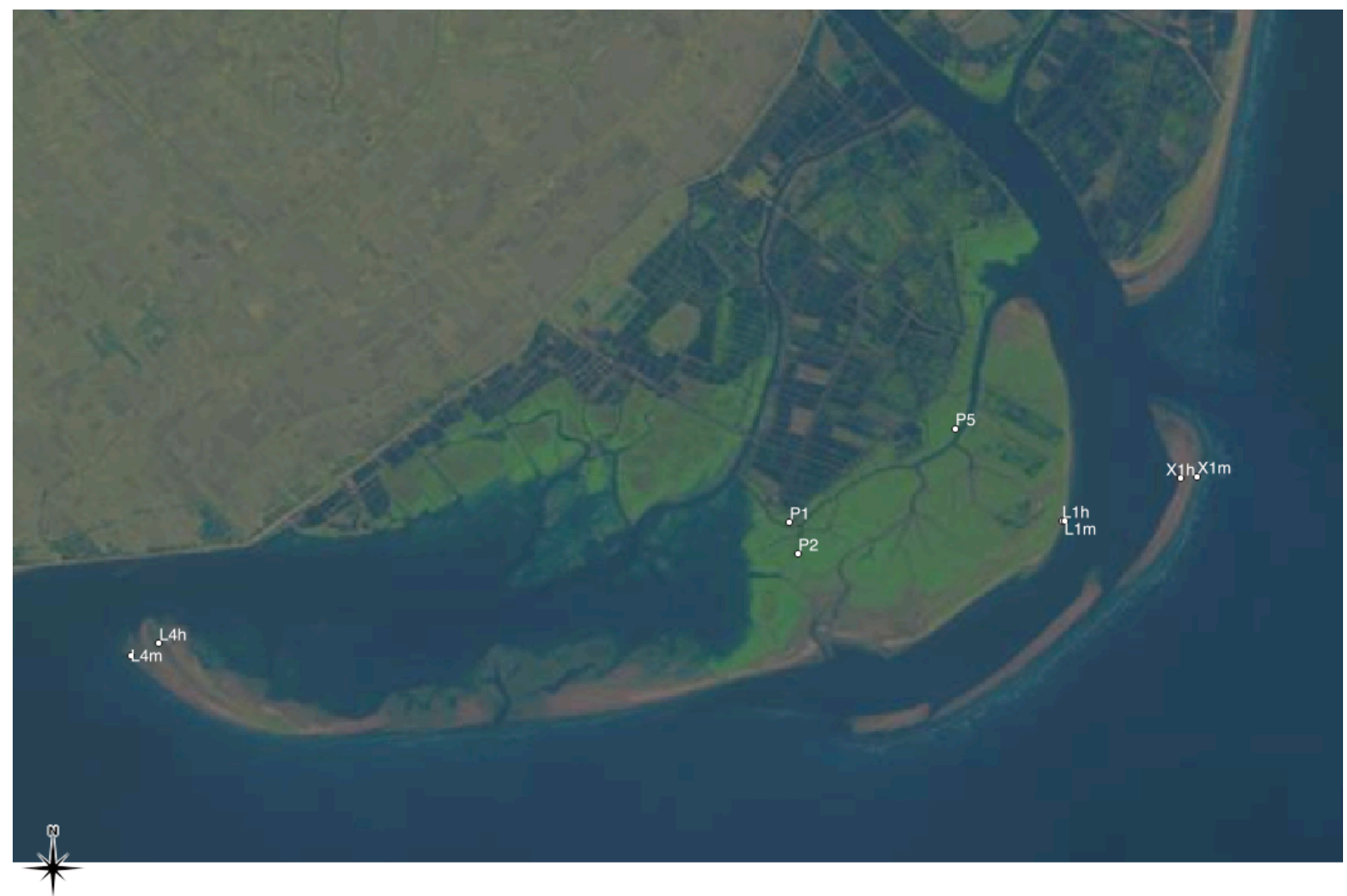

Figure 1. Locations of plots for mangrove census and quadrats for macronivertebrate species census

Source (satellite image): USGS. LandsatLook Viewer. http://landsatlook.usgs.gov/ (Dec. 27, 2013)

\subsection{Macroinvertebrate species census}

Census of macroinvertebrate species was also performed, by total counting of identified species taken from surface layer ( $50 \mathrm{~cm}$ by $50 \mathrm{~cm}$ with $30 \mathrm{~cm}$ depth) inner of each plots for mangrove species census, in order to recognize the relationships among macroinvertebrate and mangrove species.

The selected three plots for plant species census was targeted for macroinvertebrate species census for the survey of July 2013, corresponding to summer season; and in December of 2013, corresponding to winter season, in consequent with mangrove species census. In addition, quadrats in tidal flats without vegetation were established in $\mathrm{Lu}$ (L1h, L1m, L4h, and L4m) and Xanh (X1h and $\mathrm{X} 1 \mathrm{~m}$ ) islets, in order to compare the results between mangrove forest zones and sandy-flat zones without mangrove species (Figure 1).

\subsection{Analysis of collected data}

The collected data from census of mangrove species and macroinvertebrate species were analysed by single linkage (nearest neighbour) agglomerative clustering using 
the Pearson's correlation of data. And similarity indexes of all clustered variables were analysed in order to identify the correlations among them.

The dendrograms of clustering analysis outputs and similarity indexes were obtained using PAST (Paleontological Statistic) version 3.0. Single linkage with similarity indexes based on Pearson correlation was used for the clustering criteria. In addition, in order to identify indicator species, indicator value index proposed by Dufrêne and Legendre (Legendre and Legendre, 2012) was calculated for censed macroinvertebrate species. The indicator species add ecological meaning to groups of sites discovered by clustering, they provide criteria to compare typologies derived from data analysis, to identify where stop dividing clusters into subsets, and to point out the main levels in a hierarchical classification of sites (Legendre and Legendre, 2012). The indicator value index is based only on within-species abundance and occurrence comparisons; its value is not affected by the abundance of other species. The indicator value index is defined as follows. For each species $j$ in each cluster of sites $k$, one computes the product of two values, $A_{k j}$ and $B_{k j}$. $A_{k j}$ is a measure of specificity (positive predictive value) based on abundance values whereas $B_{k j}$ is a measure of fidelity (sensitivity) computed from presence data:

Specificity: where;

$$
A_{k j}=\text { Nindividuals }_{k j} / \text { Nindividual }_{+k}
$$

Nindividuals $_{k j}$ : mean abundance of species $j$ across the sites pertaining to cluster $k$

Nindividual $s_{+k}$ : sum of the mean abundance of species $j$ within the various clusters

Fidelity:

where;

$$
B_{k j}=\text { Nsites }_{k j} / \text { Nites }_{k+}
$$

Nsites $_{k j}$ : number of sites in cluster $k$ where species $j$ is present

Nsites $_{k+}$ : total number of sites in the cluster

$$
\begin{aligned}
& \text { Indicator value index: } \\
& \qquad \text { IndVal }_{k j}=A_{k j} / B_{k j}
\end{aligned}
$$

Indicator species in a given cluster should be the species which obtains the higher value of indicator value index.

\section{Results and discussion}

Usually, large expanses of tropical coastlines are inhabited by mangrove forest, to the extent that they play a major role in supporting coastal food webs and nutrient cycles in the coastal zone (Alongi et al., 2000). The foremost abundant species of mangrove observed in XTNP are Kandelia candel, Aegiceras corniculatum, Sonneratia caseoralis, and Rhizophora stylosa. In a small amount, shrubs of Acanthus ilicifolius were also identified.

Cannicci et al. (2008) emphasizes that some species of small, but very abundant crabs ubiquitous in mangrove environments are considered as ecosystem engineers, able to change the particle size distribution and to enhance soil aeration and mangrove primary production (Nielsen et al., 2003; Kristensen and Alongi, 2006; Kristensen et al., 2008). The results of macroinvertebrate species counting in quadrats inside the plots P1, P2, and P5 and tidal flats without mangrove species are listed in Table A (Appendix).

Among the 55 species identified in the surveyed quadrats, only five common species - two polychaeta, one bivalvia, and two gastropoda - were found reciprocally within mangrove area and area without vegetation. The rest, 50 species were found exclusively in mangrove areas or in areas without vegetation. The Table 1 lists the appearance of species in tidal-flats with mangroves and without vegetation, and the exclusive appearance of species. This behaviour is consistent with the statement of Nhuong and Khac (2004), observing that macroinvertebrates species of XTNP are much more diverse in mangrove forests than their surroundings. However, a species of Ampeliscidae malacostraca, the bivalvias Donax incarnatus, and a Tellina sp. showed seasonal high abundance partially in tidal-flats without mangroves. As listed in Table 1 most of the species, in both for mangrove and non-vegetated areas, appeared with seasonal preference. Among them, it is notorious the selective appearance of almost half of mangrove forest-associated gastropods in winter. According to Hogart (2007), mangrove forests offer opportunities to marine organisms, providing both a physical environment and a source of nutrients. Moreover, the dominant macroinvertebrate species associated to mangrove forests belong to two families, the Grapsidae - now generally regarded as subfamilies: the most important of these is the family Sesarmidae- and Ocypodidae. The presence of Sesarmidae species Parasesarma pictum and Sesarma plicatum, and Ocypodidae species Uca (Tabuca) arcuata and an identified $U c a$ sp. was confirmed in censed plots of mangroves in XTNP. According to Nordhaus et al. (2006), Sesarmidae crabs are less abundant, but also to have a degree of impact, consuming huge amount of mangrove species litter production. Moreover, Uca spp. process large amounts of primary production in terms of microalgae, contributing consistently in retention of mangrove production (Cannicci et al., 2008). Based on Nhuong and Wada (2004), Ocypodidae are an important group for studying tidal animals' behaviour useful as an indicator species for substrate environments in mangrove forests and river mouths.

Table 1. Appearance of macroinvertebrate species

\begin{tabular}{llrrrrrr}
\hline \multirow{2}{*}{ Phylum } & \multirow{2}{*}{ Class } & \multicolumn{2}{c}{ Tidal-flats with mangrove species } & \multicolumn{3}{c}{ Tidal-flats without vegetation } \\
& & Summer & Winter & Total & Summer & Winter & Total \\
\hline Annelida & Polychaeta & 1 & 1 & 2 & 2 & 2 & 3 \\
Arthropoda & Malacostraca & 5 & 6 & 10 & 3 & 6 & 7 \\
Mollusca & Bivalvia & 4 & 6 & 8 & 8 & 4 & 9 \\
\hline
\end{tabular}




\begin{tabular}{|c|c|c|c|c|c|c|c|}
\hline \multirow{2}{*}{ Phylum } & \multirow{2}{*}{ Class } & \multicolumn{3}{|c|}{ Tidal-flats with mangrove species } & \multicolumn{3}{|c|}{ Tidal-flats without vegetation } \\
\hline & & Summer & Winter & Total & Summer & Winter & Total \\
\hline & Gastropoda & 9 & 14 & 18 & 2 & 2 & 3 \\
\hline \multicolumn{8}{|c|}{ Seasonal and habitat exclusive appearance of macroinvertebrate species } \\
\hline \multirow{2}{*}{ Phylum } & \multirow{2}{*}{ Class } & \multicolumn{3}{|c|}{ Tidal-flats with mangrove species } & \multicolumn{3}{|c|}{ Tidal-flats without vegetation } \\
\hline & & Summer & Winter & Yearly & Summer & Winter & Yearly \\
\hline Annelida & Polychaeta & 0 & 0 & 0 & 1 & 0 & 0 \\
\hline Arthropoda & Malacostraca & 4 & 5 & 1 & 1 & 4 & 2 \\
\hline \multirow[t]{2}{*}{ Mollusca } & Bivalvia & 1 & 4 & 2 & 4 & 1 & 3 \\
\hline & Gastropoda & 4 & 8 & 5 & 0 & 0 & 1 \\
\hline
\end{tabular}

Meanwhile, the trophic position of gastropods is equally varied. Sediment dwellers feed on sediment organic matter and/or microphytobenthos. Nagelkerken et al., (2008) stated that Littoraria spp. feed on epibenthic crusts on stems and roots, and some species feed on mangrove species litter and/or propagules. In this case, Littoraria melanostoma was found in plots of XTNP where coexist A. corniculatum and $K$. candel species. According to Reid et al. (2008), all genera of Potamididae are associated with mangrove forests, using the trees for shelter, as a substrate, for food and protection from predators. A group of Potamididae species such as Cerithidea cingulata, $C$. djadjariensis, C. largillierti, C. rhizophorarum of XTNP showed presence only in plots with mangrove species.

\subsection{Cluster analysis of collected data}

Tang and $\mathrm{Yu}$ (2007) found that, the types of mangrove species communities influence the zonation of macroinvertebrate species owing to the growing environment provided by different mangrove species communities. The Table 2 lists the compilation of estimated AGB values, and censed macroinvertebrate species of XTNP.

Table 2. Compilation of data of plots P1, P2, and P5 (suffixes S: summer, W: winter)

\begin{tabular}{|c|c|c|c|c|c|c|c|}
\hline Variable & Unit & P1S & $\mathrm{P} 2 \mathrm{~S}$ & P5S & $\mathrm{P} 1 \mathrm{~W}$ & $\mathrm{P} 2 \mathrm{~W}$ & P5W \\
\hline \multicolumn{8}{|l|}{ Mangrove AGB } \\
\hline Kandelia & $\mathrm{kg} / \mathrm{m}^{2}$ & 3.54 & 0.15 & 0.43 & 3.52 & 0.15 & 0.63 \\
\hline Aegiceras & $\mathrm{kg} / \mathrm{m}^{2}$ & 0.00 & 0.03 & 2.77 & 0.00 & 0.03 & 2.77 \\
\hline Sonneratia & $\mathrm{kg} / \mathrm{m}^{2}$ & 0.00 & 1.76 & 0.00 & 0.00 & 1.75 & 0.00 \\
\hline Rhizophora & $\mathrm{kg} / \mathrm{m}^{2}$ & 0.00 & 0.08 & 0.00 & 0.00 & 0.06 & 0.00 \\
\hline Total AGB & $\mathrm{kg} / \mathrm{m}^{2}$ & 3.54 & 2.02 & 3.20 & 3.52 & 1.99 & 3.40 \\
\hline \multicolumn{8}{|c|}{ Macroinvertebrate population } \\
\hline Nephtyidae & individual $/ 0.075 \mathrm{~m}^{3}$ & 3 & 1 & 0 & 0 & 0 & 0 \\
\hline Polychaeta & individual $/ 0.075 \mathrm{~m}^{3}$ & 0 & 0 & 0 & 0 & 5 & 1 \\
\hline Cleistostoma & individual $/ 0.075 \mathrm{~m}^{3}$ & 0 & 0 & 0 & 14 & 4 & 10 \\
\hline Paracleistostoma & individual $/ 0.075 \mathrm{~m}^{3}$ & 5 & 4 & 25 & 0 & 0 & 0 \\
\hline Uca (Tubuca) & individual $/ 0.075 \mathrm{~m}^{3}$ & 6 & 0 & 0 & 0 & 2 & 1 \\
\hline Parasesarma & individual $/ 0.075 \mathrm{~m}^{3}$ & 0 & 0 & 0 & 1 & 0 & 0 \\
\hline Sesarma & individual $/ 0.075 \mathrm{~m}^{3}$ & 0 & 0 & 0 & 1 & 2 & 4 \\
\hline Helice & individual $/ 0.075 \mathrm{~m}^{3}$ & 0 & 1 & 1 & 0 & 2 & 2 \\
\hline Metaplax & individual $/ 0.075 \mathrm{~m}^{3}$ & 6 & 0 & 0 & 0 & 0 & 0 \\
\hline Laternula & individual $/ 0.075 \mathrm{~m}^{3}$ & 0 & 1 & 0 & 0 & 0 & 0 \\
\hline Pharella & individual $/ 0.075 \mathrm{~m}^{3}$ & 0 & 0 & 0 & 0 & 1 & 1 \\
\hline Brachidontes & individual $/ 0.075 \mathrm{~m}^{3}$ & 0 & 0 & 0 & 0 & 3 & 0 \\
\hline Polymesoda & individual $/ 0.075 \mathrm{~m}^{3}$ & 0 & 4 & 2 & 0 & 2 & 2 \\
\hline Glauconome & individual $/ 0.075 \mathrm{~m}^{3}$ & 0 & 0 & 0 & 0 & 2 & 0 \\
\hline Tellinidae & individual $/ 0.075 \mathrm{~m}^{3}$ & 0 & 1 & 0 & 0 & 1 & 0 \\
\hline Cyclina & individual $/ 0.075 \mathrm{~m}^{3}$ & 0 & 2 & 0 & 0 & 0 & 0 \\
\hline Veneroida & individual $/ 0.075 \mathrm{~m}^{3}$ & 0 & 0 & 0 & 0 & 1 & 0 \\
\hline Cerithidea & individual $/ 0.075 \mathrm{~m}^{3}$ & 51 & 4 & 9 & 83 & 19 & 0 \\
\hline Clithon & individual $/ 0.075 \mathrm{~m}^{3}$ & 0 & 0 & 1 & 0 & 0 & 0 \\
\hline Nereididae & individual $/ 0.075 \mathrm{~m}^{3}$ & 0 & 0 & 0 & 1 & 0 & 0 \\
\hline Odostomia & individual $/ 0.075 \mathrm{~m}^{3}$ & 2 & 0 & 0 & 260 & 0 & 1 \\
\hline
\end{tabular}




\begin{tabular}{|c|c|c|c|c|c|c|c|}
\hline Variable & Unit & P1S & $\mathrm{P} 2 \mathrm{~S}$ & P5S & P1W & $\mathrm{P} 2 \mathrm{~W}$ & P5W \\
\hline Assiminea & individual $/ 0.075 \mathrm{~m}^{3}$ & 14 & 1 & 8 & 37 & 27 & 10 \\
\hline Littoraria & individual $/ 0.075 \mathrm{~m}^{3}$ & 0 & 0 & 1 & 2 & 0 & 0 \\
\hline Rissoina & individual $/ 0.075 \mathrm{~m}^{3}$ & 0 & 0 & 0 & 5 & 0 & 0 \\
\hline Stenothyra & individual $/ 0.075 \mathrm{~m}^{3}$ & 0 & 0 & 0 & 6 & 0 & 0 \\
\hline Cylindrotis & individual $/ 0.075 \mathrm{~m}^{3}$ & 0 & 0 & 0 & 0 & 10 & 0 \\
\hline Laemodonta & individual $/ 0.075 \mathrm{~m}^{3}$ & 4 & 0 & 1 & 0 & 12 & 14 \\
\hline Gastropoda & individual $/ 0.075 \mathrm{~m}^{3}$ & 0 & 0 & 0 & 0 & 0 & 2 \\
\hline
\end{tabular}

In order to analyse the relations between mangrove species and macroinvertebrate species a combined analysis with clustering and similarity indexes was conducted. Figure 2a shows the result of cluster analysis among mangrove species AGB and macroinvertebrate species counts using data collected in July and December 2013 in P1, P2, and P5. Clustering analysis suggest that Kandelia and Aegiceras behave farther dissimilar with respect of the other species. Meanwhile, Rhizophora is quite similar to Sonneratia. In an annual basis, the associated macroinvertebrate species with Kandelia could be Cerithidea spp. and with lesser extent, gastropod species of Odostomia, Littoraria, and Stenothyra. In the same way, close association with Sonneratia and Rhizophora was observed for a species of Tellinidae bivalves. Aegiceras associated macroinvertebrate species resulted uncertain in annual basis.

In order to analyse the seasonal behaviour, similar analysis was conducted discriminating data gathered in July and December 2013. The Figure $2 b$ shows the result of cluster analysis among mangrove species AGB and macroinvertebrate species counts using data collected in July 2013 (summer season). High association of Paracleis- tostoma, Clithon, and Littoraria species was observed with Aegiceras. Also, high association with Sonneratia and Rhizophora was observed for Laternula, a Tellinidae and Cyclina species; and, occypod Uca, Metaplax decapoda, and gastropod Cerithidea, and Odostomia species with Kandelia. The high similarity of Assiminea species with AGB suggests that these gastropod molluscs are ubiquitous in mangrove areas during summer season.

The Figure 2c shows the result of cluster analysis among mangrove species $\mathrm{AGB}$ and macroinvertebrate species counts using data collected in December 2013 (winter season). A species of gastropod mollusc and Sesarma have high similarity with Aegiceras. By the other hand Sonneratia and Rhizophora are highly associated with species of bivalves Brachidontes, Glauconome, a Tellinidae, and a Veneroida; and the gastropod Cylindrotis. Meanwhile, Kandelia associated macroinvertebrate resulted for a Nereididae polychaeta, a decapod Parasesarma, a group of gastropods encompassing Stenothyra, Littoraria, Rissoina, and Odostomia species. For the winter season, Cleistostoma seems to be the ubiquitous species in the mangrove areas of XTNP. 


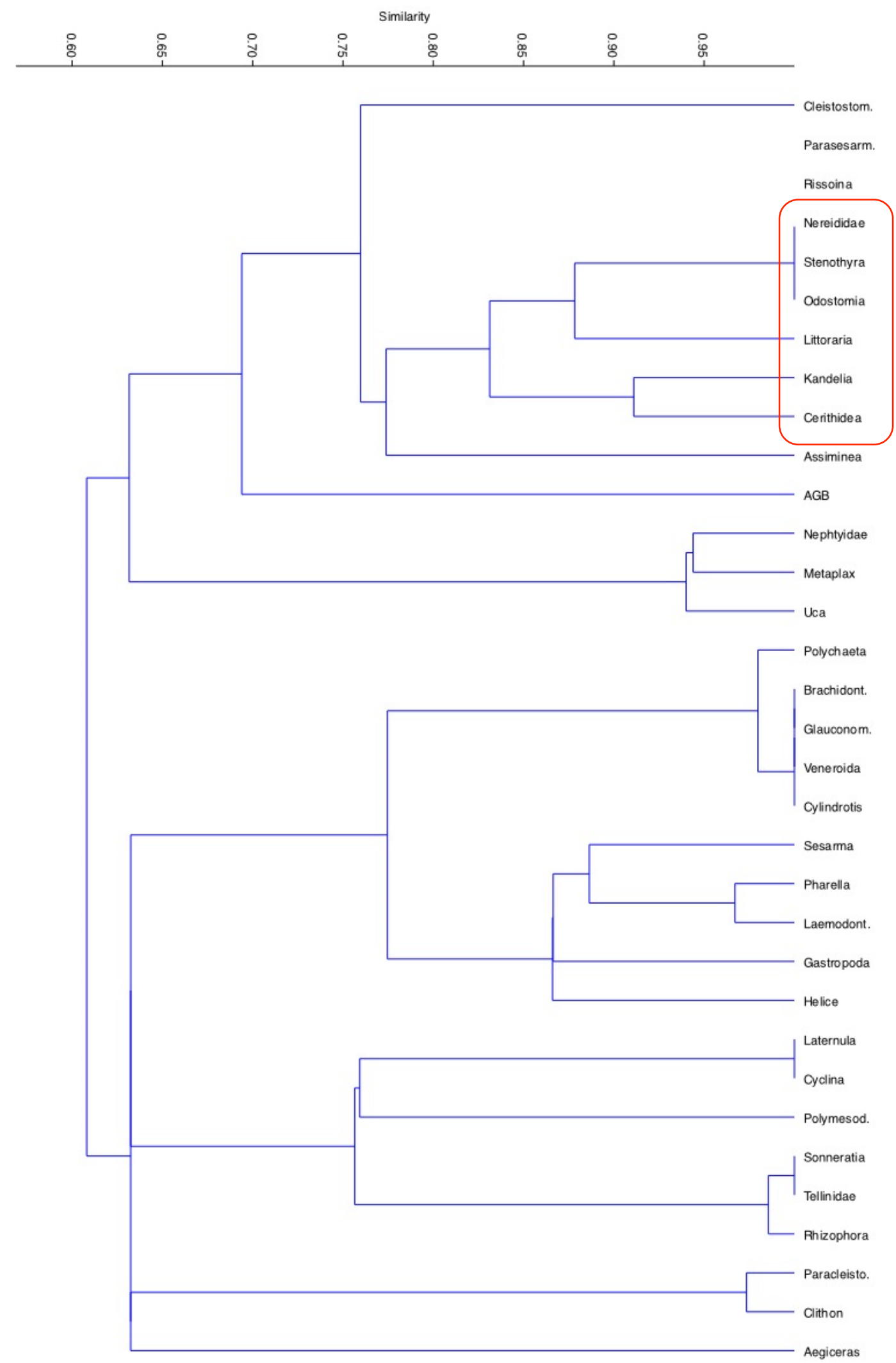

Figure 2a. Clustering dendrogram among mangrove species and macroinvertebrate species (summer and winter seasons) 


\begin{tabular}{|c|c|c|c|c|c|c|c|c|}
\hline \multicolumn{9}{|c|}{ Similarity } \\
\hline 怘 & 站 & $\stackrel{\circ}{\text { 市 }}$ & 영 & $\stackrel{\circ}{\circ}$ & 공 & $\stackrel{\circ}{\circ}$ & $\stackrel{\circ}{\infty}$ & $\stackrel{8}{\mathscr{8}}$ \\
\hline
\end{tabular}

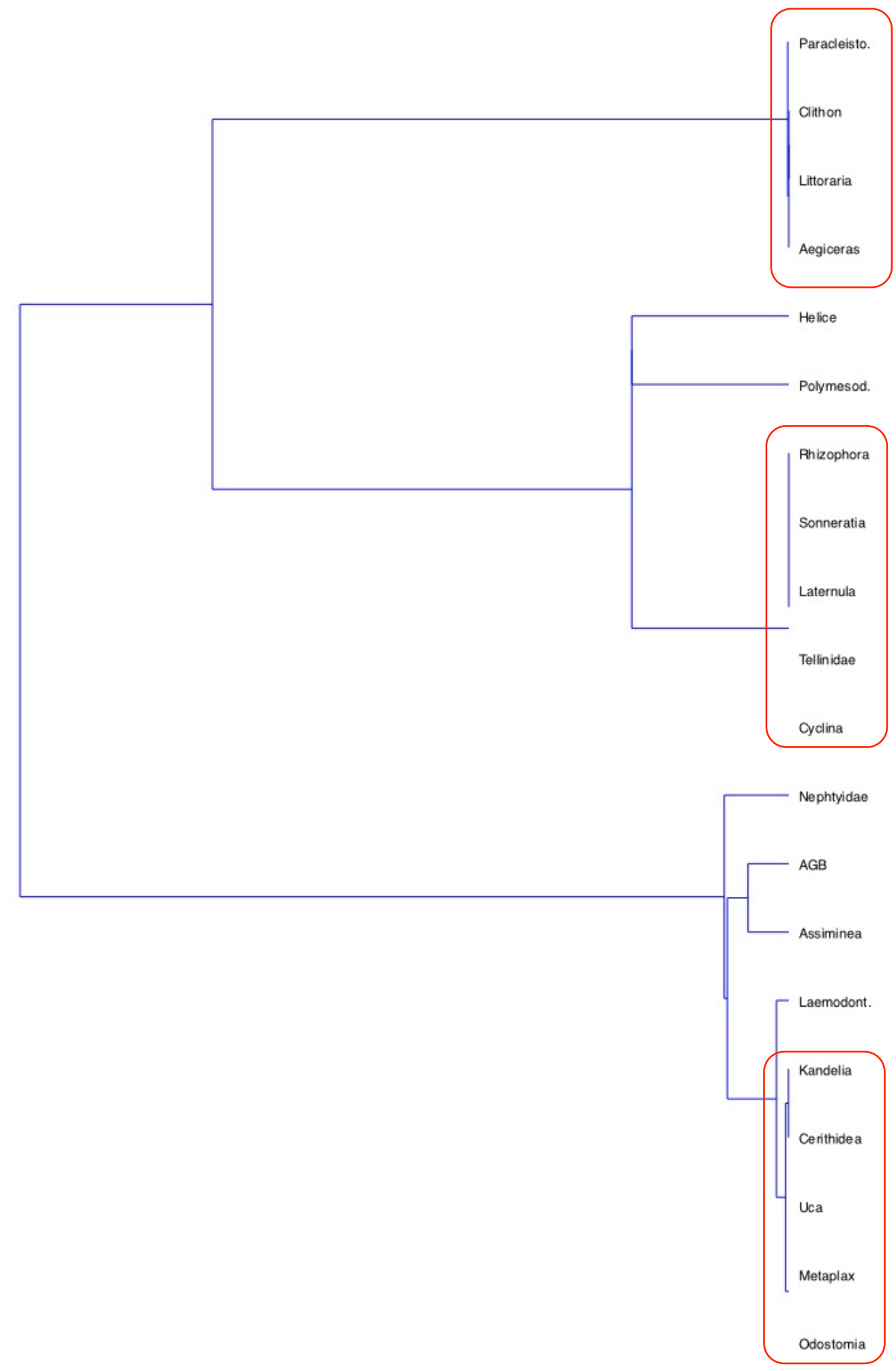

Figure 2b. Clustering dendrogram among mangrove species and macroinvertebrate species (summer season) 


\begin{tabular}{|c|c|c|c|c|c|c|c|}
\hline \multicolumn{8}{|c|}{ Similarity } \\
\hline $\begin{array}{l}\text { 苦 } \\
\text { fon }\end{array}$ & $\stackrel{\circ}{\infty}$ & 용 & $\stackrel{\circ}{\$}$ & : & 용 & $\stackrel{\circ}{\infty}$ & : \\
\hline
\end{tabular}

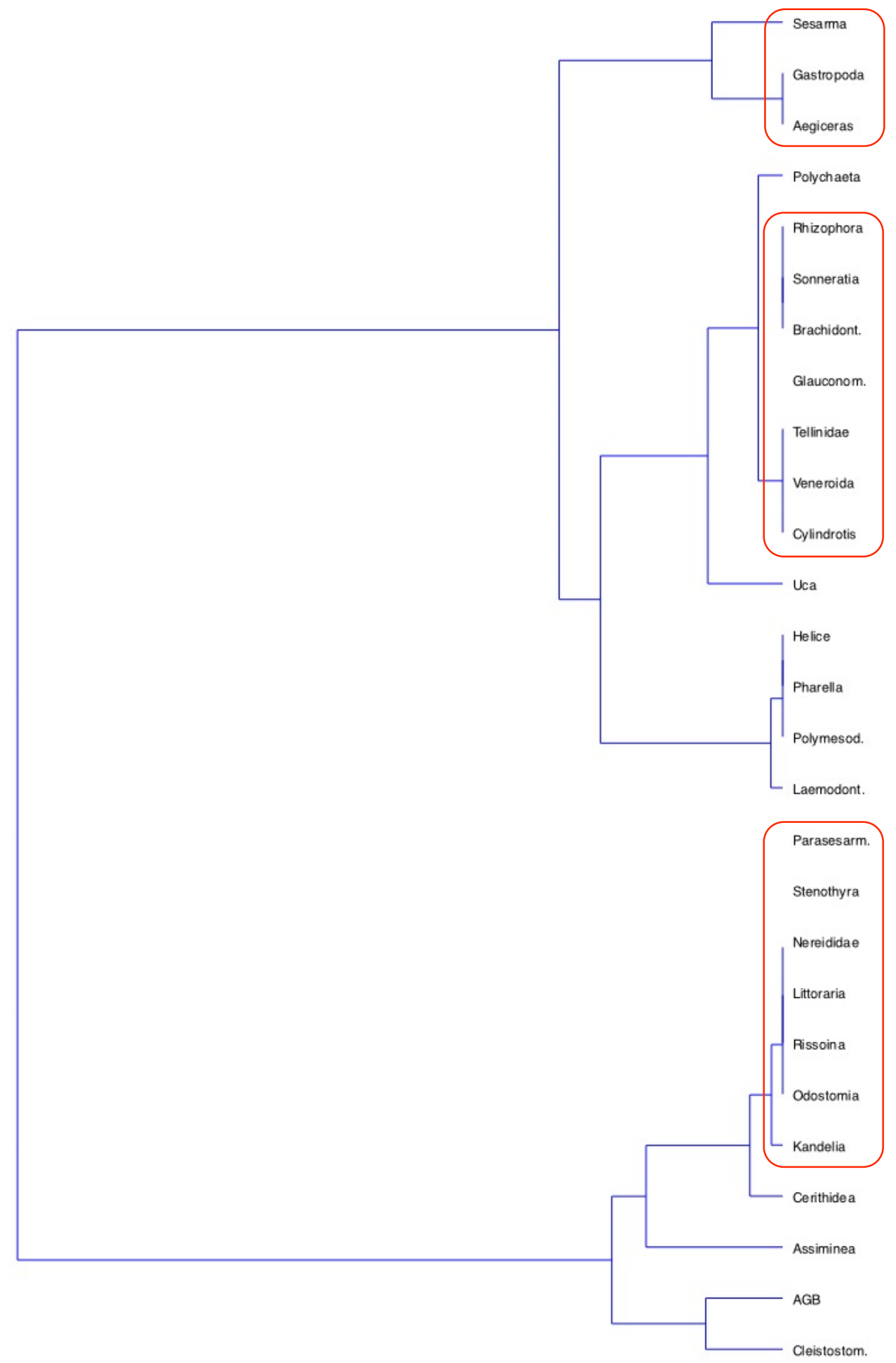

Figure 2c. Clustering dendrogram among mangrove species and macroinvertebrate species (winter season) 


\subsection{Macroinvertebrate species composition}

The Institute of Ecology and Biological Resources had been inventoried macroinvertebrate species living in XTNP. In total 355 species was recorded encompassing 47 species of polychaeta, two unidentified species of diptera, 151 of malacostraca, one maxillopoda, two mero- stomata, one lingulata (brachiopoda), one anthozoa (cnidarian), 67 bivalvia, two cephalopoda, 80 gastropoda, and one phascolosomatidea (spincula). Indicator value index of macroinvertebrate species associated to mangrove forest ecosystem was calculated using Dufrêne and Legendre method based on the field data as listed in Table A (Appendix). The results are listed in Table 3.

Table 3. Indicator value indexes of macroinvertebrate species at genus level (results of genus groups with IndVal lesser than 0.5 were discarded)

\begin{tabular}{|c|c|c|c|c|c|c|c|c|}
\hline & \multicolumn{3}{|c|}{ Summer } & \multicolumn{5}{|c|}{ Winter } \\
\hline & $\mathrm{P} 1$ & $\mathrm{P} 2$ & P5 & & $\mathrm{P} 1$ & $\mathrm{P} 2$ & $\mathrm{P} 5$ & \\
\hline \multicolumn{9}{|l|}{ Nephtyidae } \\
\hline$A_{k 1}$ & & & & 1.0 & & & & 0.0 \\
\hline$B_{k 1}$ & 1 & 1 & 0 & 0.7 & 0 & 0 & 0 & 0.0 \\
\hline IndVal $l_{k l}$ & & & & 0.7 & & & & 0.0 \\
\hline \multicolumn{9}{|l|}{ Polychaeta } \\
\hline$A_{k 2}$ & & & & 0.0 & & & & 1.0 \\
\hline$B_{k 2}$ & 0 & 0 & 0 & 0.0 & 0 & 1 & 1 & 0.7 \\
\hline IndVal $_{k 2}$ & & & & 0.0 & & & & 0.7 \\
\hline \multicolumn{9}{|c|}{$\underline{\text { Paracleistostoma }}$} \\
\hline$A_{k 3}$ & & & & 0.5 & & & & 0.5 \\
\hline$B_{k 3}$ & 1 & 1 & 1 & 1.0 & 1 & 1 & 1 & 1.0 \\
\hline $\operatorname{IndVal}_{k 3}$ & & & & 0.5 & & & & 0.5 \\
\hline \multicolumn{9}{|l|}{ Sesarma } \\
\hline$A_{k 3}$ & & & & 0.0 & & & & 1.0 \\
\hline$B_{k 3}$ & 0 & 0 & 0 & 0.0 & 1 & 1 & 1 & 1.0 \\
\hline IndVal $_{k 3}$ & & & & 0.0 & & & & 1.0 \\
\hline \multicolumn{9}{|l|}{ Pharella } \\
\hline$A_{k 3}$ & & & & 0.0 & & & & 1.0 \\
\hline$B_{k 3}$ & 0 & 0 & 0 & 0.0 & 0 & 1 & 1 & 0.7 \\
\hline $\operatorname{IndVal}_{k 3}$ & & & & 0.0 & & & & 0.7 \\
\hline \multicolumn{9}{|l|}{ Odostomia } \\
\hline$A_{k 3}$ & & & & 0.0 & & & & 1.0 \\
\hline$B_{k 3}$ & 1 & 0 & 0 & 0.3 & 1 & 0 & 1 & 0.7 \\
\hline IndVal $_{k 3}$ & & & & 0.0 & & & & 0.7 \\
\hline \multicolumn{9}{|l|}{ Assiminea } \\
\hline$A_{k 3}$ & & & & 0.2 & & & & 0.8 \\
\hline$B_{k 3}$ & 1 & 1 & 1 & 1.0 & 1 & 1 & 1 & 1.0 \\
\hline IndVal $_{k 3}$ & & & & 0.2 & & & & 0.8 \\
\hline \multicolumn{9}{|c|}{ Laemodonta } \\
\hline$A_{k 3}$ & & & & 0.2 & & & & 0.8 \\
\hline$B_{k 3}$ & 1 & 0 & 1 & 0.7 & 0 & 1 & 1 & 0.7 \\
\hline$I_{n d V a l} l_{k 3}$ & & & & 0.1 & & & & 0.6 \\
\hline
\end{tabular}

As listed in Table 3 the higher value of indicator value index (IndVal) was resulted for a Nephtyidae species $(0.7)$ for the summer season and genus of Sesarma (1.0) for the winter season; and for annual basis, Paracleistostoma genus $(0.5$ and 0.5$)$.

\section{Conclusions}

The macroinvertebrate species of XTNP can be classified by those species preferring mangrove forest areas and those for sandy-flats without mangrove species. Among the 55 species, only five species were found in both areas. Furthermore, seasonal abundance of species in both areas was observed. The result of cluster analysis among the macroinvertebrate and mangrove species inferred high association of macroinvertebrates with a specific species of mangroves. Cerithidea, Odostomia, Littoraria, and Stenothyra gastropod species correlated with $K$. candel. With A. corniculatum, crabs of Paracleistostoma genus and the gastropod Clithon in summer season, while Sesarma crabs and a species of gastropoda in winter season. Also, a Tellinidae species correlated with $S$. caseoralis and $R$. stylosa in an annual basis. Based on the results using the method of indicator value index it is recommended to define as indicator species of macroinvertebrates for annual basis and others for seasonal basis. The spatially and seasonally ubiquitous Paracleistostoma crabs are the foremost suitable candidates for macroinvertebrate species. In addition, a Nephtyidae species for summer and Sesarma species for winter season is also recommended as indicator species of macroinvertebrates. 


\section{Appendix}

Table A. Macrinvertebrate species accounts in 2013 (unit: individuals/0.075 $\mathrm{m}^{3}$ )

\begin{tabular}{|c|c|c|c|c|c|c|c|c|c|c|c|c|c|c|c|c|c|c|}
\hline \multirow{2}{*}{ Species } & \multicolumn{2}{|c|}{ P1 } & \multicolumn{2}{|c|}{$\mathbf{P 2}$} & \multicolumn{2}{|c|}{ P5 } & \multicolumn{2}{|c|}{ L1m } & \multicolumn{2}{|c|}{ L1h } & \multicolumn{2}{|c|}{$\mathbf{L} 4 \mathbf{m}$} & \multicolumn{2}{|c|}{ L4h } & \multicolumn{2}{|c|}{$\mathrm{X} 1 \mathrm{~m}$} & \multicolumn{2}{|c|}{$\mathrm{X} 1 \mathrm{~h}$} \\
\hline & $\mathbf{S}$ & $\mathbf{W}$ & $\mathbf{S}$ & $\mathbf{W}$ & $\mathbf{S}$ & $\mathbf{W}$ & $\mathbf{S}$ & $\mathbf{W}$ & $\mathbf{S}$ & $\mathbf{W}$ & $\mathbf{S}$ & $\mathbf{W}$ & $\mathbf{S}$ & $\mathbf{W}$ & $\mathbf{S}$ & $\mathbf{W}$ & $\mathbf{S}$ & $\mathbf{W}$ \\
\hline Glyceridae & & & & & & & & & & & 2 & & & & 9 & & 1 & \\
\hline Nephtyidae & 3 & & 1 & & & & 21 & 8 & & 21 & 9 & & & & & & & \\
\hline Polychaeta & & & & 5 & & 1 & & 11 & & & & 1 & & 16 & & 4 & & \\
\hline Ampeliscidae & & & & & & & & 167 & & & & & & & & 8 & & 20 \\
\hline Corophiidae & & & & & & & & & & 1 & & 1 & & & & & & \\
\hline Alpheus pubescens & & & & & & & & 1 & & 1 & & & & & & & & 1 \\
\hline Cleistostoma dilatatum & & 14 & & 4 & & 10 & & & & & & & & & & & & \\
\hline Paracleistostoma depressum & 4 & & 4 & & 25 & & & & & & & & & & & & & \\
\hline Paracleistostoma sp. & 1 & & & & & & & & & & & & & & & & & \\
\hline Dotilla wichmanni & & & & & & & 5 & 6 & 2 & 7 & 19 & 6 & 33 & 1 & 80 & 5 & 10 & 19 \\
\hline Macrophthalmus dilatatus & & & & & & & & & & & & & & & 2 & & & \\
\hline Ocypode ceratophthalmus & & & & & & & & & & & & & & 1 & & & 1 & \\
\hline Uca (Tubuca) arcuata & 6 & & & 2 & & & & & & & & & & & & & & \\
\hline Uca sp. & & & & & & 1 & & & & & & & & & & & & \\
\hline Parasesarma pictum & & 1 & & & & & & & & & & & & & & & & \\
\hline Sesarma plicatum & & 1 & & 2 & & 4 & & & & & & & & & & & & \\
\hline Helice formosensis & & & 1 & & 1 & & & & & & & & & & & & & \\
\hline Helice latimera & & & & 2 & & 2 & & & & & & & & & & & & \\
\hline Metaplax sheni & 6 & & & & & & & & & & & & & & & & & \\
\hline Isopoda & & & & & & & & & & 1 & & & & & & & & \\
\hline Laternula truncata & & & 1 & & & & & & & & & & & & 1 & & & \\
\hline Pharella acutidens & & & & 1 & & 1 & & & & & & & & & & & & \\
\hline Solen strictus & & & & & & & & & & & & & & & 4 & & & \\
\hline Brachidontes striatulus & & & & 3 & & & & & & & & & & & & & & \\
\hline Polymesoda coaxans & & & 4 & 2 & 2 & 2 & & & & & & & & & & & & \\
\hline Donax incarnatus & & & & & & & & 3 & & & 935 & 2 & 22 & 5 & & 52 & 1 & \\
\hline Glauconome curta & & & & 2 & & & & & & & & & & & & & & \\
\hline Tellina sp. & & & & & & & 41 & 28 & & 56 & & & & & 219 & & & \\
\hline Tellinidae & & & 1 & 1 & & & & & & & & & & & & & & \\
\hline Cyclina sinensis & & & 2 & & & & & & & & & & & & & & & \\
\hline Dosinia japonica & & & & & & & & & & & 1 & & & & & & & \\
\hline Meretrix lyrata & & & & & & & & & & & & & & & 1 & & & \\
\hline Meretrix meretrix & & & & & & & & & & 1 & & & & & 24 & & & \\
\hline Veneridae & & & & & & & & & & & & & & & 1 & & & \\
\hline Veneroida & & & & 1 & & & & & & & & & & & & & & \\
\hline Bivalvia & & & & & & & & & & & & & & 1 & & & & \\
\hline Cerithidea cingulata & 36 & & 1 & & & & & & & & & & & & & & & \\
\hline Cerithidea djadjariensis & & 30 & & 5 & & & & & & & & & & & & & & \\
\hline Cerithidea largillierti & 13 & 46 & 3 & 5 & 9 & & & & & & & & & & & & & \\
\hline Cerithidea rhizophorarum & 1 & & & & & & & & & & & & & & & & & \\
\hline Cerithidea sp. & 1 & 7 & & 9 & & & & & & & & & & & 1 & & & \\
\hline Clithon oualaniensis & & & & & 1 & & & & & & & & & & & & & \\
\hline Nereididae & & 1 & & & & & & & & & & 2 & & & & & & \\
\hline Odostomia sp. & 2 & 260 & & & & 1 & & & & & & & & & & & & \\
\hline Assiminea lutea & 14 & 37 & 1 & 23 & 8 & 10 & & & & & & & & & & & & \\
\hline
\end{tabular}




\begin{tabular}{|c|c|c|c|c|c|c|c|c|c|c|c|c|c|c|c|c|c|c|}
\hline \multirow{2}{*}{ Species } & \multicolumn{2}{|c|}{ P1 } & \multicolumn{2}{|c|}{$\mathbf{P 2}$} & \multicolumn{2}{|c|}{ P5 } & \multicolumn{2}{|c|}{ L1m } & \multicolumn{2}{|c|}{ L1h } & \multicolumn{2}{|c|}{$\mathbf{L} 4 \mathbf{m}$} & \multicolumn{2}{|c|}{ L4h } & \multicolumn{2}{|c|}{$\mathrm{X} 1 \mathrm{~m}$} & \multicolumn{2}{|c|}{ X1h } \\
\hline & $\mathbf{S}$ & $\mathbf{W}$ & $\mathbf{S}$ & $\mathbf{W}$ & $\mathbf{S}$ & $\mathbf{W}$ & $\mathbf{S}$ & $\mathbf{W}$ & $\mathbf{S}$ & $\mathbf{W}$ & $\mathbf{S}$ & $\mathbf{W}$ & $\mathbf{S}$ & $\mathbf{W}$ & $\mathbf{S}$ & $\mathbf{W}$ & $\mathbf{S}$ & $\mathbf{W}$ \\
\hline Assiminea sp. & & & & 4 & & & & & & & & & & & & & & \\
\hline Littoraria melanostoma & & 2 & & & 1 & & & & & & & & & & & & & \\
\hline Glossaulax didyma & & & & & & & & & & & 4 & 2 & & & & 1 & & \\
\hline Rissoina sp.1 & & 5 & & & & & & & & & & & & & & & & \\
\hline Stenothyra polita & & 6 & & & & & & & & & & & & & & & & \\
\hline Cylindrotis quadrasi & & & & 10 & & & & & & & & & & & & & & \\
\hline Laemodonta octanfracta & & & & 12 & & & & & & & & & & & & & & \\
\hline Laemodonta punctatostriata & & & & & & 14 & & & & & & & & & & & & \\
\hline Laemodonta siamensis & 4 & & & & 1 & & & & & & & & & & & & & \\
\hline Gastropoda & & & & & & 2 & & & & & & & & & & & & \\
\hline
\end{tabular}

S: summer (July 2013); W: winter (December 2013)

\section{References}

[1] Alongi, D. M., Tirendi, F. and Clough, B. F. 2000. Below-ground decomposition of organic matter in forests of the mangroves Rhizophora stylosa and $A v$ icennia marina along the arid coast of Western Australia. Aquatic Botany 68: 97-122.

[2] Cannicci, S., Burrows, D., Fratini, S., Smith III, T.J., Offenberg, J., and Dahdouh-Guebas, F. 2008. Faunal impact on vegetation structure and ecosystem function in mangrove forests: a review. Aquatic Botany 89: 186-200.

[3] Giesen, W., Wulffraat, S., Zieren, M. and Scholten, L. 2006. Mangrove Guidebook for Southeast Asia. FAO and Wetlands International.

[4] Haneji, C., Amemiya, T., Itoh, K., Mochida, Y., Nhan, H.T.T., and Cu, P.V. 2014. Analysis of environmental stressors on ecosystems of XTNP, Vietnam. Journal of Vietnamese Environment. Vol. 5, No. 1, pp. 12-21.

[5] Hogarth, P. J. 2007. The Biology of Mangroves and Seagrasses. Oxford University Press. ISBN 978-019-856871-1.

[6] Hong, P.N., Tuan, L.X., and Dao, P.T.D. 2007. XTNP Biodiversity. MERC-MCD, Hanoi, Vietnam.

[7] Komiyama, A., Moriya, H., Prawiroatmodjo, S., Toma, T., Ogino, K., 1988. Forest primary productivity. In: Ogino, K., Chihara, M. (Eds.), Biological System of Mangrove. Ehime University, pp. 97-117.

[8] Kristensen, E., and Alongi, D. M., 2006. Control by fiddler crabs (Uca vocans) and plant roots (Avicennia marina) on carbon, iron, and sulfur biogeochemistry in mangrove sediment. Limnology and Oceanography 51: 1557-1571.

[9] Kristensen, E., Bouillon, S., Dittmar, T., and Marchand, C. 2008. Organic carbon dynamics in mangrove ecosystems: a review. Aquatic Botany 89: 201-219.

[10] Legendre, P. and Legendre, L. 2012. Numerical Ecology. Third English edition. Elsevier. ISBN:

\section{8-0-444-53868-0.}

[11] Nagelkerken, I., Blaber, S. J. M., Bouillon, S., Green, P., Haywood, M., Kirton, L. G., Meynecke, J-O, Pawlik, J., Penrose, H. M., Sasekumar, A., and Somerfield, P. J. 2008. The habitat function of mangroves for terrestrial and marine fauna: A review. Aquatic Botany 89:155-185.

[12] Nielsen, O. I., Kristensen, E., and Macintosh, D. J. 2003. Impact of fiddler crabs (Uca spp) on rates and pathways of benthic mineralization in deposited shrimp pond waste. Journal of Experimental Marine Biology and Ecology. 289: 59-81.

[13] Nhuong, D. V. and Khac, H. N. 2004. Data on benthos in the mangrove areas of the Red River mouth. Mangrove Ecosystem in the Red River Coastal Zone. Agricultural Publishing House, Hanoi. (Hong, P. N. eds).

[14] Nhuong, D. V. and Wada, K. Some characteristics of Ocypodidae - Brachyura in the mangrove ecosystem of Giao Thuy District, Nam Dinh Province. Mangrove Ecosystem in the Red River Coastal Zone. Agricultural Publishing House, Hanoi. (Hong, P. N. eds).

[15] Nordhaus, I., Wolff, M., and Diele, K. 2006. Litter processing and population food intake of the mangrove crab Ucides cordatus in a high intertidal forest in northern Brazil. Estuarine, Coastal and Shelf Science. 67: 239-250.

[16] Reid, D. G., Dyal, P., Lozouet, P., Glaubrecht, M., and Williams, S. T. 2008. Mudwhelks and mangroves: The evolutionary history of an ecological association (Gastropoda: Potamididae). Molecular Phylogenetics and Evolution 47: 680-699.

[17] Tang, Y. and Yu, S. 2007. Spatial zonation of macrobenthic fauna in Zhanjiang Mangrove Nature Reserve, Guangdong, China. Acta Ecologica Sinica 27(5): 1703-1714.

[18] Tue, N. T., Ngoc, N. T., Quy, T. D., Hamaoka, H., 
Nhuan, M. T., and Omori, K. 2012. A cross-system analysis of sedimentary organic carbon in the mangrove ecosystems of XTNP, Vietnam. Journal of Sea Research 67: 69-76.
[19] Wösten, J. H. M., de Willigen, P., Tri, N. H., Lien, T. V., Smith, S. V., 2003. Nutrient dynamics in mangrove areas of the Red River Estuary in Vietnam. Estuarine, Coastal and Shelf Science 57: 6572 . 